\title{
PEMANFAATAN WHATSAPP GROUP DALAM PENGIMPLEMENTASIAN NILAI-NILAI KARAKTER PANCASILA PADA ERA DISRUPSI
}

\author{
Oleh \\ Ricu Sidiq
}

\begin{abstract}
ABSTRAK
Penelitian ini bertujuan untuk mengetahui group pada apliksi whatsApp dimanfaatkan sebagai wadah diskusi dalam pengimplementasian nilai-nilai karakter Pancasila para penggunanya. Dalam proses penggunaan, nilai-nilai karakter Pancasila perlu di implementasikan oleh setiap pengguna, guna menghindari perilaku negatif, berita bohong, dan menimbulkan konflik-konflik di dalam masyarakat. Metode yang digunakan didalam penelitian ialah metode penelitian kualitatif dengan pendekatan studi kasus pada ruang diskusi maya atau WA group dalam pengimplementasian nilai-nilai karakter pancasila. Sumber data dalam penelitian dibedakan menjadi 2 jenis, yaitu data primer dan data sekunder. Data primer merupakan data yang diperoleh secara langsung melalui pengamatan dari WA Group kelas Mandiri 2016 Pendidikan Sejarah, Universitas Negeri Medan. Pengamatan ini digunakan sebagai teknik pengambilan data yang dilihat dari interaksi sosial, Sementara, untuk data sekunder diperoleh melalui studi pustaka atau library research. Hasil penelitian ialah pemanfaatan WhatsApp Group dalam pengimplementasian nilai-nilai karakter Pancasila pada era disrupsi dengan menggunakan peraturan-peraturan dalam ruang diskusi sehingga terciptanya tukar pikiran, musyawarah, dan pengambilan keputusan menggunakan bahasa saling menghormati, bebas dan bertanggungjawab.
\end{abstract}

Kata Kunci : Group, WhatsApp, Karakter. 


\section{PENDAHULUAN}

Dewasa ini, dunia terus-menerus mengalami perkembangan yang begitu pesat. Perkembangan dunia kini telah mencapai pada era disrupsi, di mana segala hal bergerak maju kedepan dalam berbagai aspek kehidupan. Perindustrian, Pendidikan, pertanian, teknologi dan informasi mendapatkan perubahan yang signifikan dan sangat besar, mulai dari skala yang terkecil hingga yang terbesar. Manusia adalah agen utama yang menggerakkan itu semua. Mencipta, menginovasi dan memperbarui dilakukan untuk tujuan mempermudah semua aktivitas dalam kehidupan sehari-hari.

Perubahan (disrupsi) yang sekarang ini terjadi akibat revolusi industri 4.0 (Industrial Revolution 4.0). Perubahan tersebut sangat terlihat dalam ranah teknologi komunikasi yang terus bergerak dengan cepat dan menggantikan alat teknologi yang sudah ada dengan alat baru yang lebih sempurna. Hasil penginovasian semuanya serba disruptif, dimulai dari tersedianya jaringan internet, smartphone, mesin cetak, penghitung digital, google, hingga transportasi listrik. Hal itu memungkinkan semua orang untuk berperan aktif didalamnya dan mengambil keuntungan yang begitu besar pada pekerjaannya.

Hal yang begitu penting dan memegang peranan dalam era disrupsi yang populer dan banyak diminati semua orang serta sebagaian besar bisa dimiliki dan dimanfaatkan adalah produk-produk teknologi, seperti internet. Tersedianya internet memberikan dampak besar bagi perusahaan dibidang teknologi informasi maupun penggunanya. Perusahaan pada bidang teknologi informasi tahap demi tahap meluncurkan produk-produknya, mereka menamainya dengan layanan komunikasi berbasis internet. Semua terkemas dalam digital dengan semua fiturfiturnya sesuai kebutuhan pengguna.

Teknologi informasi komunikasi telah menjalar kesemua badan kehidupan yang dapat dirasakan langsung manfaatnya dan diyakini bisa mengatasi kesenjangan manusia, salah satunya adalah sosial media. Berbagai jenis sosial media bermunculan sebagai wadah untuk berkomunikasi, berdiskusi, bertukar pikiran, saling kenal mengenal, dan menjalin bisnis. Misalnya akun media sosial WhatsApp, facebook, instagram, blackberry messenger, twitter, dan lain 
sebagainnya. Perubahan yang cepat (disrupsi) yang terjadi pada media sosial menjadikannya sebagai wadah komunikasi dengan semua orang di seluruh dunia. Pergerakan komunikasi tanpa sadar mendorong semua orang untuk masuk kedalam sistemnya. Baik buruk yang didapatkan setelah memakainya seakan tidak menjadi penghalang bagi semua orang dan dilihat dengan mata buram.

Media sosial seperti whatsApp memberikan daya tarik yang luar biasa, banyak terjadi peralihan dari media sosial sebelumnya ke media sosial ini. Orangorang menganggap bahwa whatsApp merupakan wadah komunikasi, penyalur perasaan, dan pikiran yang handal dan sempurna. WhatsApp memiliki laju perkembangan yang begitu pesat, menembus dinding-dinding pembatas komunikasi.

Dampak positifnya sangat dirasakan di era revolusi industri 4.0 masa ini, manusia menjadikannya sebagai wadah berdiskusi dengan relasinya dengan grupgrup yang dibuat di dalam aplikasi whatsApp. Kebebasan setiap individu terlaksanakan di dalamnya seakan-akan tidak ada sekat pembatas. Isu politik, ekonomi, religius, dan sosial terdorong untuk disalurkan secara perlahan oleh penggunanya tanpa pertimbangan-pertimbangan kritis dalam menanggapinya. Masyarakat dari berbagai kalangan merupakan penggunanya, tak terkecuali siswa atau mahasiswa juga terlibat aktif mengambil peran di ruangan maya tersebut. Seiring perkembangannya, whatsApp menjadi ruang diskusi utama bagi siswa atau mahasiswa. Setelah terjadinya pembelajaran di sekolah, maka terjadilah sebuah proses tanpa absen dan kepentingan di group-group yang telah dibuat.

Terjadinya disrupsi pada teknologi komunikasi akibat revolusi industri 4.0 juga menimbulkan masalah pada penggunanya. Setidaknya ada beberapa permasalahan yang dapat dilihat. Terjadinya fenomena-fenomena negatif pada bidang sosial, hukum, politik, dan ekonomi dapat dilihat dan dicermati seiring perkembangan dan perubahan (disrupsi) pada teknologi informasi. Selain pada aspek-aspek tersebut, juga terjadi pada penurunan moral, yaitu dijadikannya ajang penyampaian ujaran kebencian, dan penipuan oleh orang-orang yang tidak bertanggungjawab. Perlunya pemikiran kritis dalam menggunakannya, dengan tujuan agar tercapainya komunikasi yang baik dan santun. 
Berdasarkan hal di atas, maka whatsApp sebagai wadah diskusi perlu di sandingkan nilai-nilai karakter yang terdapat pada Pancasila. Sehingga dalam paper ini rumusan masalahnya adalah bagaimana group pada whatsApp dimanfaatkan sebagai wadah diskusi dalam pengimplementasian nilai-nilai karakter Pancasila para penggunanya. Dalam proses penggunaan, nilai-nilai karakter Pancasila perlu di implementasikan oleh setiap pengguna. Tujuannya untuk menghindari perilaku negatif, berita bohong, dan menimbulkan konflik-konflik di dalam masyarakat.

WhatsApp sebagai media diskusi juga perlu adanya pola penafsiran yang baik pada setiap penggunaanya. Dengan group diskusi ini bisa dilakukan pembiasaan diri, pembinaan dan wadah pemahaman nilai-nilai karakter Pancasila disamping diimplementasikan. Nilai-nilai karakter Pancasila yang sebelumnya rendah pemahaman masyarakat dan belum terlaksanakan dengan sepenuhnya mendapatkan tempat di whatsApp group.

Tantangan-tantangan pada era disrupsi akibat revolusi industri 4.0 kedepannya akan berkurang dengan diimplementasikannya nilai-nilai karakter Pancasila di dalam whatsApp group oleh para pengguna. WhatsApp group sebagai wadah pengimplementasian nilai-nilai karakter Pancasila di era disrupsi dapat memberikan dampak pada kualitas moral para pengguna dan ideologi bangsa akan terjamin keutuhannya.

Metode penelitian yang digunakan ialah metode penelitian kualitatif dengan pendekatan studi kasus pada ruang diskusi maya atau whatsApp group dalam pengimplementasian nilai-nilai karakter pancasila. Rahardjo (2017) dalam makalahnya yang berjudul Studi Kasus Dalam Penelitian Kualitatif : Konsep dan Prosedur mengatakan bahwa studi kasus merupakan kegiatan ilmiah yang terstruktur, terinci dan mendalam tentang suatu program, aktivitas, peristiwa didalam suatu kelompok orang, lembaga, atau organisasi untuk mendapatkan informasi tentang sebuah kasus yang sedang berlangsung atau yang sudah terjadi.

Sumber data dalam penelitian dibedakan menjadi 2 jenis, yaitu data primer dan data sekunder. Data primer merupakan data yang diperoleh secara langsung melalui pengamatan dari whatsApp Group kelas Mandiri 2016 Pendidikan Sejarah, Universitas Negeri Medan. Pengamatan ini digunakan sebagai teknik pengambilan 
data yang dilihat dari interaksi sosial, penggunaan bahasa, saling menghormati, dan sebagainya. Para peneliti turut serta dalam segala aktivitas yang dilakukan didalam ruang diskusi atau whatsApp Group. Data primer juga diperoleh dari hasil wawancara terhadap para anggota dan admin group. Peneliti mengajukan beberapa pertanyaan kepada informan mengenai situasi diskusi grup dalam pengimplementasian nilai-nilai karakter pancasila. Sementara,untuk data sekunder diperoleh melalui studi pustaka atau library research.

Untuk mengkonfirmasi kebenaran data, peneliti melakukan tringulasi temuan. Dimana temuan peneliti dilaporkan kepada informan yang diwawancara untuk mendapatkan data yang sesuai dan objektif. Dan simpulan penelitian, peneliti meringkas ulang temuannya dengan penggunaan teori yang relevan dan penggunaan data yang telah didapatkan dilapangan.

\section{PEMBAHASAN}

Media sosial WhatsApp (WA) merupakan salah satu media komunikasi yang saat ini banyak digandrungi oleh seluruh lapisan masyarakat. Penggunaan media sosial WA ini sudah menjadi salah satu media sosial yang mencakup keseluruhan kepentingan masyarakat dalam berkomunikasi memenuhi keperluan masing-masing. Jubile Enterprise (2012) mendefinisikan whatsapp sebagai aplikasi chatting dimana anda bisa mengirim pesan teks, gambar, suara, lokasi dan bahkan video ke orang lain dengan menggunakan smartphone apapun. WhatsApp dalam penggunaannya sebagai media chat digital yang mencakup, pesan teks, gambar, video, dan dapat untuk menelpon menjadi satu kesatuan yang lengkap untuk membantu masyarakat dalam menjalin komunikasi di seluruh belahan dunia. Suryadi (2018) menambahkan jika dilihat dari fungsinya WhatsApp hampir sama dengan aplikasi SMS yang biasa dipergunakan di ponsel lama. Namun, WhatsApp ini tidak menggunakan pulsa seperti biaya sms pada umumnya, pada WhatsApp ini menggunakan jaringan internet sesuai dengan perkembangan teknologi yang saat ini terhubung dengan jaringan dan teridentifikasi dengan nomor HandPhone (HP). Aplikasi WhatsApp ini juga dilengkapi dengan berbagai pilihan yang mendukung seperti adanya New Group, New Broadcast, WhatsApp Web, Starred Messages and 
Settings. Fitur lengkap yang tersedia di aplikasi Whatsapp membuat penggunanya semakin meningkat pesat. Hingga bulan Februari 2016, tercatat penguna aktif Whatsapp mencapai 1 miliar tiap bulannya (Zamroni, 2017).

Berbagai pilihan yang tersedia di WhatsApp tersebut ada salah satunya bernama New Group yang belakangan ini banyak digunakan para pelajar, mahasiswa dan dosen sebagai media komunikasi yang terhalang oleh jarak yang disebut bernama WA Group. WA Group tersebut saat ini dijadikan wadah diskusi untuk memecahkan berbagai masalah, pertanyaan dan sesuatu yang penting yang harus disampaikan terhadap orang-orang yang tergabung di dalamnya. Diskusi melalui WA Group ini sangat membantu penggunanya untuk berkomunikasi dalam kepentingan mereka masing-masing, dalam penggunaannya tidak sembarangan menggunakan ada aturan dan nilai-nilai Pancasila yang harus diterapkan sehingga tetap menjaga ketentraman dalam berdiskusi tanpa tatap muka atau digital tersebut. Nilai-nilai Pancasila yang dapat diterapkan dalam penggunaan WA Group ini dapat dimulai dari ketika bertanya sesuatu dimulai dengan mengetik salam disertai dengan kalimat yang santun untuk menyampaikan tujuan dari pesan tersebut. WA Group ini juga memiliki Admin Group yang merupakan orang yang memiliki sedikit kelebihan dapat memasukan dan mengeluarkan siapa-siapa saja yang dapat bergabung di group tersebut bahkan Admin Group ini dapat membuat teman lainnya menjadi Admin Group juga seperti dirinya.

Damanhuri (2016) menyebutkan bahwa Pancasila merupakan ideologi dasar bagi negara Indonesia dan untuk menjadi warga negara yang baik (good citizen) di Indonesia harus sesuai dengan Pancasila dan Undang-Undang Dasar 1945. Penggunaan WA Group yang baik juga menjadi salah satu contoh menjadi warga Negara yang baik maka pentingnya pengimplementasian nilai-nilai Pancasila tersebut dalam membangun karakter bangsa. Pengimplementasian nilai-nilai Pancasila dalam diskusi WA Group menjadi salah satu yang harus diperhatikan untuk menjaga kenyamanan orang-orang yang tergabung dalam group tersebut dan komunikasi dapat tetap berjalan dengan lancar. Nilai-nilai Pancasila dalam membangun karakter bangsa tersebut sudah dapat dikatakan ada ketika WA Group sudah dibuat dan memiliki anggota di dalam WA Group tersebut. Ketika sudah 
berkumpul dan ada yang melempar pertanyaan yang masih belum diketahui kepastiannya dalam Group tersebut, kemudian ada yang menanggapinya sudah dapat dikatakan bermusyawarah untuk memecahkan masalah.

Perubahan yang terjadi saat ini atau yang disebut dengan Era Disrupsi dapat berjalan sesuai dengan jati diri bangsa Indonesia dengan senantiasa mengimplementasikan nilai-nilai Pancasila dari sesuatu yang sederhana. Sehingga bangsa Indonesia dalam mengalami perubahan ke arah teknologi yang canggih ini tidak kehilangan jati diri dan dapat tetap mempertahankan karakter bangsa Indonesia. Dalam rangka lebih memperkuat pelaksanaan pendidikan karakter pada satuan pendidikan telah teridentifikasi 18 nilai yang bersumber dari agama, Pancasila, budaya, dan tujuan pendidikan nasional, yaitu: (1) Religius, (2) Jujur, (3) Toleransi, (4) Disiplin, (5) Kerja keras, (6) Kreatif, (7) Mandiri, (8) Demokratis, (9) Rasa Ingin Tahu, (10) Semangat Kebangsaan, (11) Cinta Tanah Air, (12) Menghargai Prestasi, (13) Bersahabat/Komunikatif, (14) Cinta Damai, (15) Gemar Membaca, (16) Peduli Lingkungan, (17) Peduli Sosial, (18) Tanggung Jawab (Wahyudi, 2009). Nilai-nilai yang telah teridentifikasi dalam pendidikan karakter bangsa tersebut dapat menjadi salah satu acuan bangsa Indonesia untuk senantiasa mengimplementasikannya dalam seluruh kegiatan dimana pun berada, salah satunya saat berada di dunia Maya.

Pengimplememtasian nilai-nilai karakter pancasila dalam WA Group diperlukan peraturan-peraturan dalam penggunaannya. Hal ini dilakukan dalam upaya pencegahan tersebarnya berita-berita palsu, perilaku menyimpang dari oknum-oknum yang tidak bertanggung jawab. Sejumlah peraturan yang diterapkan dalam WA group sebagai ruang diskusi memiliki peranan penting dalam penyampaian aspirasi atau pendapat para penggunanya seperti, diskusi antar mahasiswa, maupun masyarakat. Adapun peraturan-peraturan dalam penggunaan WA Group sebagai ruang diskusi ialah : 


\section{Adanya Admin}

Fungsi admin di dalam WA Group merupakan sebagai penerima anggota. Admin menyeleksi para calon anggota untuk bergabung dalam ruang diskusi. Selain itu, Admin juga mengkoordinir setiap anggota agar berprilaku sopan, menghargai pendapat orang lain, jujur dalam ruang diskusi.

\section{Adanya Sanksi}

Fungsi dari sanksi di dalam WA Group merupakan sebagai bentuk hukuman apabila para anggota memberikan informasi palsu, tidak beretika, bertindak sewanang-wenang dalam ruang diskusi.

\section{Peraturan dalam Berdiskusi}

Pengimplementasian nilai-nilai pancasila diperlukan sejumlah peraturan dalam berdiskusi. Seperti, jujur, saling menghormati, adil, objektif, dan sebagainya. Hal ini ditujukan agar para anggota memiliki karakter yang sesuai dalam nilai-nilai pancasila di ruang publik. Terlepas dari aturan-aturan yang telah disebutkan diatas, kesadaran dari pengguna WhatsApp group juga sangat diharapkan untuk terus dikembangkan. Ketika aturan-aturan telah dibuat dan diberlakukan tetapi penggunanya sendiri kurang memiliki kesadaran untuk mengimplementasikan nilai-nilai yang terkandung dalam butir-butir Pancasila tersebut dalam kegiatan diskusi jarak jauh maka hal tersebut juga tidak akan dapat berjalan ataupun terlaksana sesuai dengan tujuan yang telah dirumuskan. Tetap saja akan terjadi halhal yang menyimpang dari nilai-nilai yang terkandung dalam Pancasila seperti tidak menghargai pendapat dari orang lain dan merasa lebih memiliki hak dalam menentukan sesuatu hal.

Penggunaan WhatsApp sebagai ruang diskusi untuk menumbuh kembangkan karakter Pancasila dalam setiap individu juga sangat memiliki peluang dalam pengimplementasian nilai-nilai tersebut dalam kehidupan sehari-hari. Seperti yang telah diketahui bersama bahwa dewasa ini anak-anak muda lebih banyak menghabiskan waktunya dengan gadget, smartphone ataupun telepon selulernya. Mereka lebih nyaman dan sangat menikmati berdiskusi dengan ruang-ruang diskusi yang telah disediakan oleh perangkat-perangkat tersebut, salah satu yang populer 
saat ini seperti yang telah dijelaskan diatas yaitu whatsApp group. Ketika seorang individu telah terbiasa berdiskusi melalui whatsApp group dengan selalu mengimplementasikan nilai-nilai atau karakter yang terkandung dalam Pancasila maka hal tersebut dapat diasumsikan akan ia terapkan pula dalam kehidupan seharihari, yaitu seperti diskusi langsung didunia nyata. Individu tersebut akan sangat dengan mudah untuk menerapkannya karena ia telah terbiasa mengimplementasikannya di dunia maya.

Ketika dewasa ini hampir seluruh fasilitas di sosial media yang dapat berakibat fatal atau buruk terhadap penggunanya, namun melalui pengimplementasian nilai-nilai karakter Pancasila inilah diharapkan mampu menjadi salah satu cara yang dapat digunakan untuk menumbuh kembangkan nilainilai karakter Pancasila. Tidak hanya akan diimplementasikan dalam kegiatan diskusi di dunia maya tetapi juga di dunia nyata.

\section{PENUTUP}

Teknologi informasi khususnya media social seperti WhatsApp sebagai wadah diskusi dengan fitur groupnya dapat dimanfaatkan sebagai wadah pengimplemetasian nilai-nilai karakter Pancasila kepada para penggunanya. Era disrupsi akibat dari revolusi industry 4.0 memberikan tantangan-tantangan yang sangat besar pada masyarakat lauas. Pemikiran kritis sangat diperlukan dalam setiap melihat semua perkembangan yang ada.

Adanya group WhatsApp ini akan memberikan pengaruh, baik positif maupun negatif. Pemanfaatan yang tepat adalah salah satu tuntutan wajib yang harus dimiliki oleh pengguna. Masalah-masalah yang ditimbulkan dapat diatasi dengan mengimplementasikan nilai-nilai karakter Pancasila pada setiap diskusi. Sehingga para pengguna tetap berada pada jalurnya, hal-hal yang tidak diinginkan dapat diminimalisasikan.

Timbulnya sikap saling menghargai dan menghormati, kedewasaaan dalam berpikir dan bertintak membuat pemanfaatan group WhatsApp sangat berguna menimbulkan suasana keakraban karena menggunakan bahasa yang saling mendukung dalam hal positif, berbagi informasi yang positif yang dimiliki, terjadi 
umpan balik antara peserta group, bahkan dapat memecahkan masalah dengan membuat kesepakatan di group WhatsApp sehingga menghilangkan keterbatakan ruang dan waktu.

Pembelajaran dengan memanfaatkan group WhatsApp yang sedang digemari oleh mahasiswa dapat meningkatkan afektif dan efektifitas, sehingga dapat mengikuti perkembangan zaman dan tidak tertinggal dan didukung dengan cara dosen membuat bahan ajar yang bersifat digital.

\section{Referensi}

Damanhuri, dkk. (2016). Implementasi Nilai-Nilai Pancasila Sebagai Upaya Pembangun Karakter Bangsa (Studi Kasus di Kampung Pancasila Desa Tanjung Sari Kecamatan Pabuaran Kabupaten Serang). Jurnal Untirta Civic Education. Vol. 1.

Jubile Enterprise. (2012). Chatting Tanpa Batas Menggunakan Whatsapp. Jakarta : PT Elex Media Komputindo.

Rahardjo, M. (2017). Studi Kasus Dalam Penelitian Kualitatif : Konsep dan Prosedurnya. Malang : Universitas Islam Negeri Maulana Malik Ibrahim.

Salamah, Alim. (2018). Penguatan Integrasi Nasional Di Era Disrupsi Dalam Perspektif Pancasila. Universitas. Prosiding Seminar Nasional PKn UNNES. Hal. 26-40.

Suryadi. E, dkk.(2018). Penggunaan Sosial Media WhatsApp dan Pengaruhnya Terhadap Disiplin Belajar Peserta Didik Pada Mata Pelajaran Pendidikan Agama Islam (Studi Kasus di SMK Analis Kimia YKPI Bogor). Jurnal Pendidikan Islam. Vol. 7. No. 1.

Wahyudi. (TT) Reaktualisasi Nilai-nilai Pancasila Dalam Pembangunan Karakter Bangsa Indonesia. Prosiding Seminar Nasional Inovasi Pendidikan Inovasi Pembelajaran Berbasis Karakter Dalam Menghadapi Masyarakat Ekonomi ASEAN.

Zamroni, G.M. (2017). Analisis Forensik Aplikasi Instan Messanger Berbasis Android. Annual Research Seminar. Vol 2. No1. 